Vol. 6, No. 1, April 2018, pp. 5 8

\title{
Representasi Nilai-Nilai Islami pada Web Series Animasi Nussa
}

Ilhami Resti Asih ${ }^{1}$

${ }^{1}$ Universitas Ahmad Dahlan Yogyakarta, Indonesia

\begin{tabular}{l} 
Article Info \\
\hline Article history: \\
Received Jan 17, 2018 \\
Accepted Apr 3, 2018 \\
\hline
\end{tabular}

\section{Keywords:}

Representasi

Nilai Nilai Islam

Web Series

Animasi Nussa

\begin{abstract}
Penelitian ini bertujuan untuk mengetahui bagaimana representasi nilai-nilai islami pada web series animasi Nussa. Metode yang digunakan oleh penelitian ini adalah pendekatan kualitatif. Penelitian ini menggunakan teori representasi. Teknik pengumpulan data yang dipakai adalah teknik dokumentasi, observasi dan wawancara. Objek penelitian ini adalah web series animasi Nussa dengan mengambil empat episode berdasarkan viewers terbanyak, episode tersebut adalah episode Tidur Sendiri Tidak Takut, episode Dahsyatnya Basmallah, episode Jangan Boros, episode Rara Sakit. Hasil penelitian dari empat episode berdasarkan viewers terbanyak adalah yang pertama terdapat Islam direpresentasikan oleh animasi Nussa seperti: Pakaian Muslim, memelihara dan menyayangi salah satu hewan kucing yang merupakan hewan peliharaan dan kesayangan Nabi Muhammad SAW, kaligrafi, berdo'a agar dijauhkan dari gangguan syaitan. Sedangkan untuk nilainilai Islami yang direpresentasikan oleh animasi Nussa seperti berikut, pertama nilai aqidah: keyakinan dan kepercayaan seorang hamba terhadap Allah SWT, keyakinan sifat boros merupakan sifat dari setan. Kedua nilai ibadah: melakukan doa sebelum tidur atau adab tidur, beristigfar, membaca do'a. Ketiga nilai akhlak: berpakaian dalam Islam, adab bersin, mengucapkan terimakasih, mengucap salam dan menjawab salam, meminta maaf.
\end{abstract}

This is an open access article under the CC BY-SA license.

\section{Corresponding Author:}

Ilhami Resti Asih

Program studi Ilmu Komunikasi

Universitas Ahmad Dahlan,

Email: ilhami@comm.uad.ac.id

\section{PENDAHULUAN}

Media saat ini sangatlah berkembang pesat, dimana teknologi pada saat ini sudah sangat canggih seperti adanya media baru yang tersedia melalui telepon, satelit, komputer dan internet (Atmadja, Nengah Bawa, dkk, 2018:161). Media massa ini sangat berpengaruh pada kehidupan manusia, dimana media massa tidak bisa dipisahkan lagi oleh manusia, karena sudah menjadi suatu kebutuhan manusia untuk mendapatkan informasi. Media massa terdapat banyak jenis salah satunya adalah film. Ada beberapa jenis film, salah satunya film animasi yang tayang di YouTube dalam bentuk web series. Web series merupakan salah satu format penayangan baru yang ditayangkan melalui YouTube dengan genre yang berbeda-beda ( Anzani Wilda Aulia, 2018:19). Salah satunya adalah film pendek animasi yang berepisode ditayangkan secara berkala. Animasi merupakan gambar yang dibuat sehingga menghasilkan gerakan. Proses dalam pembuatan animasi ini tidaklah singkat melainkan prosesnya cukup panjang, yang beberapa pembuatannya ada menggunakan komputer dengan cara manual, seperti nantinya akan dibuat dengan alat tersebut. Beberapa proses yang akan dibuat, seperti dalam pembuatan efek, suara, gambar dan lain-lainya. 
Film Animasi ini salah satu tontonan yang menarik dan lucu, hal itulah yang membuat anak-anak sangat suka dengan animasi dan menjadi salah satu tontonan yang menghibur mereka seperti, animasi SpongeBob, Doraemon, Naruto, Upin Ipin dan lain-lainya. Tontonan yang banyak digemari oleh anak-anak adalah animasi. Animasi ini biasanya lebih banyak ditonton melalui televisi, namun dengan seiring perkembangan pada masa kini, untuk mendapatkan suatu tontonan tidak hanya melalui televisi lagi, melainkan dengan menggunakan media sosial seperti adanya YouTube kita dapat menonton sebuah tayangan seperti di televisi, akan tetapi untuk menonton sebuah tayangan apa lagi yang menonton anak-anak sebagai orang tua harus selalu mengawasi, karena tontonan yang ada di televisi atau media sosial tidak semuanya memberikan hal yang baik, melainkan terdapat juga tontonan yang gambarannya tidak baik, yang akan menjadi berpengaruh kepada anak-anak.

Perfilman di Indonesia saat ini sudah sangat maju dan sudah memiliki kualitas yang bagus. Jika menyinggung film animasi, di Indonesia sempat dipandang sebelah mata, karena kualitas animasinnya belum bagus. Animasi yang telah muncul di televisi atau di media sosial sebagian besar berasal dari luar Nusantara, sehingga menjadikan anak-anak di Indonesia lebih familiar dengan animasi yang bukan berasal dari Indonesia, akan tetapi ada animasi yang telah menggemparkan masyarakat di Indonesia yaitu animasi Nussa dalam bentuk web series.

Animasi Nussa merupakan animasi yang bertemakan tentang agama Islam dan dapat dibilang sangat berkaitan bagi anak-anak dan remaja masa kini. Selain itu, animasi Nussa ini adalah animasi yang tidak hanya ditonton oleh anak-anak saja, akan tetapi animasi tersebut juga dapat ditonton oleh orang dewasa seperti salah satunya orang tua yang memiliki anak, karena di dalam animasi Nussa ini juga menceritakan keseharian dalam suatu keluarga, dimana orang tua mengajari atau menasehati anak-anaknya, seperti yang kita lihat di dalam animasi Nussa terdapat seorang ibu yang kerap dipanggil dengan sebutan Umma oleh kedua anaknya. Umma ini dapat memberikan contoh bagi orang tua bagaimana cara mendidik dan mengajari serta memberi nasehat kepada anak-anaknya dengan baik. Animasi Nussa di setiap episodenya memang tidak terlepas dari nilai Islam, akan tetapi ada beberapa episode yang dibuat sedikit general dari segi visualnnya tetap Islami namun dari katakata, narasi, dan musikalnya sedikit general. Animasi Nussa adalah animasi yang cukup populer saat ini di kalangan masyarakat, yang rilis perdananya pada akun YouTube Nussa Official. Animasi Nussa juga tidak hanya ditayangkan melalui YouTube, tetapi juga sudah tayang di salah satu stasiun televisi dan saluran berbayar. Dengan munculnya animasi Nussa ini membawa ketenangan bagi orang tua, apalagi yang ingin memberikan pemahaman tentang agama Islam untuk anak-anaknya. Animasi yang bernuansa Islami seperti animasi Nussa dapat dijadikan sebuah media untuk mengenal Islam. Melalui animasi dapat kita jadikan sebagai sarana dakwah dan alat komunikasi untuk mensyiarkan Islam terhadap anak-anak, remaja dan orang tua. Adanya animasi ini yang didukung dengan kemajuan teknologi, memudahkan kita untuk berdakwah dengan menggunakan media massa dan media sosial.

Rumah produksi The Little Giantz adalah tempat dimana animasi Nussa diproduksi. Animasi Nussa menceritakan Nussa sebagai kakak laki-laki dan Rara sebagai adik perempuan serta ibu yang sering dipanggil dengan sebutan Umma. Animasi Nussa ini adalah salah satu animasi yang dibuat kekinian. Seperti yang ada di trailer animasi Nussa, terdapat adegan yang terlihat seperti seorang vlogger. Pada saat animasi Nussa mengeluarkan episode pertamanya langsung masuk trending di YouTube Indonesia yang menduduki posisi 10 besar, tidak hanya episode pertamannya yang masuk trending, tetapi episode berikut-berikutnya juga memasuki trending 10 besar, seperti beberapa episodenya yang memasuki trending, episode Tidur Sendiri Tidak Takut menjadi trending di 5 besar YouTube dan episode Dahsyatnya Basmalah menduduki trending 3. Trendingnya animasi Nussa ini yang begitu luar biasa sepertinya ada kehausan yang sangat luar biasa jadi orang Indonesia itu untuk mendapatkan suatu tontonan-tontonan yang bermanfaat seperti referensi untuk anak-anak, karena sebagai orang tua tentunya sangat khawatir dengan adanya animasi dan referensi lainnya yang disukai oleh anak-anak jarang menawarkan kebaikan apalagi menawarkan kebaikan Islam, yang dimana lebih cenderung pada kekerasan, perkelahian, tidak mendidik dan bermanfaat. Animasi Nussa sangat menarik untuk diteliti karena animasi Nussa adalah salah satu animasi yang memberikan pemahaman keislaman bagi anak-anak. Dapat kita ketahui betapa pentingnya nilai-nilai Islam bagi kita umat muslim, apalagi bagi anak-anak yang baru belajar atau mengenal Islam, karena di usia yang masih dini 3-16 tahun, mereka akan mudah meniru apa yang mereka dengar dan apa yang mereka lihat. Oleh karena itu penulis memilih "Nussa dan Rara" sebagai objek penelitian dan menjadikan uraian di atas sebagai latar belakang masalah dan judul skripsi penulis sebagai judul "Representasi Nilai-nilai Islami Pada Web Series Animasi Nussa."

Kerangka pemikiran ini merupakan suatu uraian yang dimana pernyataan tentang kerangka konsep dan pemecahan suatu masalah yang telah dirumuskan. Adanya kerangka pemikiran ini sebagai bentuk alur pikiran yang sesuai untuk menjawab suatu masalah yang berdasarkan pada landasan teoritik dan hasil penelitian yang relavan. 


\section{METODE}

Pentingnya suatu metode yang tepat dan jelas untuk mendukung suatu penelitian. Metode penelitian ini adalah cara untuk memecahkan suatu masalah dalam penelitian yang dilaksanakan dengan terencana, untuk mendapatkan fakta dan kesimpulan. Metode penelitian juga merupakan cara kerja untuk memahami daan lebih mendalami suatu objek yang di teliti. Dengan melalui metode yang jelas dan tepat. Jenis penelitian yang digunakan adalah penelitian dengan pendekatan kualitatif dan menggunkan teori representasi. Dalam penelitian kualitatif ini berperan sebagai alat yang mendukung penelitian kualitatif. Suatu penggambaran secara katakata, tertulis maupun tersirat dari orang-orang sesuai dengan perilaku yang diamati oleh peneliti merupakan penelitian yang menghasilkan data, salah satu definisi dari Bigdan dan Taylor (Moeloeng, 2002:3). Penelitian ini mengkaji tentang representasi nilai-nilai Islami pada web series animasi Nussa.

\section{HASIL DAN PEMBAHASAN}

\section{Web Series Animasi Nussa}

Animasi Nussa adalah termasuk film pendek dalam bentuk web series. Animasi Nussa merupakan animasi yang dibuat oleh 4stipe, salah satunya yang sangat berpengaruh dalam animasi Nussa ini, seorang animator yang sudah memiliki banyak pengalaman beliau adalah Aditya Triantoro, karena memang animasi Nussa adalah salah satu karya dari beliau. Animasi Nussa ini banyak mendapat pujian dari masyrakat Indonesia dan tidak hanya Indonesia tetapi di luar Nusantara, Nussa juga banyak mendapat pujian serta dukungan. Animasi Nussa dibuat dalam konsep Islami, karena di Indonesia mayoritas agama Islam dan berlandaskan dengan kurangnya tontonan-tontonan edutaimen, akan tetapi ada beberapa juga episode Nussa dapat di tonton secara umum, maksudnya secara umum itu adalah tidak hanya ditonton oleh umat muslim saja, karena penyampaian pada episode-episode tersebut dibuat secara jeneral.

\section{Representasi Nilai-nilai Islami}

Representasi adalah hal yang sangat penting, representasi dilakukan sebagai proses pengambaran terhadap suatu hal kehidupan yang dapat di gambarkan seperti melalui media, representasi juga dapat diuraikan sebagaimana keterwakilan dalam suatu budaya masyarakat melalui simbol yang diproduksi dalam proses komunikasi dan makna yang dibangun melalui proses tersebut, hal ini seperti yang sudah dijelaskan di bab sebelumnya. Gambaran-gambaran atau makna yang sudah direpresentasikan dengan baik pada sebuah film dapat menjadikan contoh bagi penonton untuk kehidupan sehari-harinya. Peneliti ini membahas tentang representasi nilai-nilai Islami. Dalam Animasi Nussa ini banyak yang dapat dikaji didalamnya, akan tetapi peneliti hanya fokus pada kajian peneliti yaitu nilai-nilai Islami. Dalam animasi Nussa terdapat nilai-nilai Islami yang ditemukan dari berbagai sudut yang digambarkan para tokoh animasi Nussa. Nilai-nilai Islami terdapat pada beberapa nilai seperti, Nilai Akidah, Nilai Ibadah, Nilai Akhlak.

\section{KESIMPULAN}

Pada web series animasi Nussa ini peneliti hanya mengambil 4 episode yaitu, Tidur sendiri Tidak Takut, Dahsyatnya Bismillah, Rara Sakit dan Jangan Boros yang dipilih berdasarkan viewers terbanyak. Jika disimpulkan dari keempat episode tersebut Islam direpresentasikan pada animasi Nussa seperti berikut: Pakaian Muslim, memelihara dan menyayangi salah satu hewan kucing yang merupakan hewan peliharaan dan kesayangan Nabi Muhammad SAW, kaligrafi, berdo'a agar dijauhkan dari gangguan syaitan. Sedangkan nilainilai Islami yang terdiri dari nilai aqidah, nilai ibadah, nilai akhlak yang direpresentasikan pada animasi Nussa seperti berikut. (1) Nilai Aqidah: keyakinan dan kepercayaan seorang muslim terhadap Allah SWT, keyakinan sifat boros merupakan sifat dari syaitan. (2) Nilai Ibadah: melakukan do'a sebelum tidur atau abdab sebelum tidur, istigfar, membaca do'a. (3) Nilai Akhlak: berpakaian dalam Islam, adab bersin, mengucapkan terima kasih, mengucap salam dan menjawab salam, meminta maaf.

\section{REFERENSI}

Atmadja, Nengah Bawa. 2018. Soiologi Media Prespektif Teori Kritis. Depok: Rajawali Pers. PT. Rajagrafindo Persada.

Bara Bima Hardika. 2018. Representasi Identitas Anak Dalam Animasi Upin Ipin Musim Episode 11. Volume 5. Halaman 2. Jurnal Online Mahasiswa (JOM) FISIP.

Burton, Graeme. 2008. Media dan Budaya Populer. Yogyakarta: penerbit Jalasutra.

Danesi, Marcel. 2012. Pesan Tanda dan Makna buku teks dasar mengenai Semiotika dan Teori Komunikasi. Jalasutra.

Darmawan, Deni. 2013. Metode penelitian Kualitatif. Bandung. PT. Remaja Rosdakarya.

Gita Aprinta E. B. 2011. Representasi Girl Power Wanita Modern Dalam Media Online. The Messenger. Volume 2/No. 2. Halaman 16 dan 17. Journal. Journal.usm.ac.id \&gt; artical \&gt; viewFile. 
Hawi, Akmal. 2014. Dasar-dasar Studi Islam. Pt RajaGrafindo Persada, jakarta.

Jawas, Yazid bin Abdul Qadir. 2014. Prinsip Dasar Islam menurut Al- Qur'an dan As- Sunnah yang Shahih. Tim pustaka At- Taqwa. Bogor Jawa Barat.

Kinung Nuril Hidayah. 2015. Representasi nilai-nilai Islam dalam film sang murabi.

Kinung Nuril Hidayah. 2015. Representasi nilai-nilai Islam dalam film sang murabi. Jurnal Commonline Departe Komunikasi. Volume 4/No. 1. Halaman 185. journal.unair.ac.id. Representasi Nilai-nilai islam dalam Film Sang Murabbi.

Meleong, Lexy J. 2002. Metodologi Penelitian Kualitatif. Rosdakarya. Bandung.

Meleong, Lexy J. 2010. Metodologi Penelitian Kualitatif. Remaja Rosdakarya. Bandung.

Muhamad Rahmad Luhur. 2017. Repesentasi Nilai-nilai Agama Dalam Film Dokumenter Indonesia Bukan Negara Islam Karya Jason Iskandar. Volume 4/No. 2. Halaman 9. Jurnal Online Mahasiswa (JOM). jom.unri.ac.id

Purwasito, Andrik. 2015. Komunikasi Multikultural. Pustaka Belajar. Celeban Timur UH III/548 Yogyakarta 55167.

Soubur, Alex. 2013. Semiotika Komunikasi. PT Remaja Rosdakarya. Bandung.

Vera, Nawiroh. 2014. Semiotika dalam Riset Komunikasi. Penerbit Ghalia Indonesia, Warung Nangka, Ciawi Bogor. 